\title{
The use of the 'Heinemanns Rote Spatlese' variety as the initial form in the Ribes rubrum selection
}

\author{
Olga Golyaeva, and Olga Panfilova* \\ Russian Research Institute of Fruit Crop Breeding (VNIISPK), 302530 Orel, Russian Federation
}

\begin{abstract}
Red currant is a valuable berry crop. The assortment is improved through the selection of new varieties. In the Russian Research Institute of Fruit Crop Breeding (Russia), breeding work for red currant has been carried out since 1984. The 'Heinemanns Rote Spatlese' variety, selected in Germany in 1942 by crossing the Prince Albert variety with Andenken an Lorgus (type of multiflowered currant - Ribes multiflorum Kit. ex Schult.), was widely used as the initial form in crosses. The greatest breeding value was shown by the family 'Rote Spatlese' $\times$ 'Jonkheer van Tets', from which 7 varieties of red currant were obtained: Asora, Valentinovka, Dana, Dar Orla, Ogonyok, Orlovchanka, Podarok Leta. The combinations in which 2 varieties were selected were also effective: 'Rote Spatlese' $\times$ 'Red Lake' - Bayana (white-fruited), Selyanochka; 'Rote Spatlese'×'Minnesota' - Osipovskaya, Orlovskaya Zvezda; 'Rote Spatlese' $\times$ 'Maarse's Prominent' - Marmeladnitsa, Ustina. The research results show that the cultivar 'Rote Spatlese ' is a valuable initial form in red currant selection for late ripening, long-raceme, high productivity. Based on the 'Rote Spatlese' genotype, VNIISPK has created 13 latematuring, high-yielding varieties of red currant, 9 of them are included in the State Register of Breeding Achievements approved for use in the Russian Federation.
\end{abstract}

\section{Introduction}

Red currant is a berry plant of temperate climate, which has nutritional value and therapeutic effect $[1,2]$. In many European countries, this crop is cultivated on an industrial scale. In recent years, the interest in red currant has also increased among Russian producers and processors of berry products. In increasing the cultivation profitability of any agricultural crop, including currants, the main role is played by the variety. Modern varieties of red currant should have high stable yield, resistance to pathogens harmful to the crop, wide response rate to environmental stress factors, be suitable for mechanized harvesting or produce high-quality berries for fresh products market $[3,4,5]$. The crop assortment is improved through the selection of new varieties. Creating a variety is a long

\footnotetext{
*Corresponding author: us@vniispk.ru
} 
process that takes time and material resources. To speed up and improve the selection efficiency, it is necessary to have genetic collections of sources and donors of important economic and biological traits for the culture. The selection effectiveness largely depends on the choice of the initial forms.

The red currant variety 'Heinemanns Rote Spatlese' was bred in Germany in 1942 by crossing the Prince Albert variety with Andenken an Lorgus (type of multi-flowered currant - Ribes multiflorum Kit. ex Schult.). This species grows in southern and south-eastern Europe on the slopes of mountains and in shrubs [6] and is distinguished by very long raceme, on which there are up to 50 flowers. Basically, the species was involved in the current selection for this trait. The descendant inherited a long flower raceme from the species form, bearing 22-28 flowers. It has a complex of economically useful features: highly productivity, self-fertilization with natural self-pollination is very high - $58 \%$, resistant to many fungal diseases, relatively resistant to currant gall mite. A characteristic feature is a long period of organic rest, so it does not suffer from sudden temperature changes. Late flowering, very late ripening. The 'Rote Spatlese' variety is mainly of industrial-use. The berries are light red, of medium size (on average $0.5 \mathrm{~g}$ ), aligned in the raceme. The pulp is acidic, contains: dry substances - $16.8 \%$, sugars $-9.1 \%$, organic acids $2.7 \%$, ascorbic acid $-46.6 \mathrm{mg} / 100 \mathrm{~g}$. The shrubs are medium-sized, poor-branching, the shoots are thick, straight. A characteristic varietal feature is a large leaf, strongly pubescent on the underside [7].

The 'Rote Spatlese' variety was widely used in selection programs as the initial form [8], on its basis many new highly productive, long-raceme varieties of red currant, which are of great commercial importance, were created.

In the Institute of Fruit and berry breeding (Wageningen, the Netherlands) in 19801990, based on the 'Rote Spatlese' variety genome, varieties that are widely distributed today were obtained: 'Rotet', 'Rosetta' ('Jonkheer van Tets' $\times$ 'Rote Spatlese'), 'Rolan' ('Fay's Prolific' × 'Rote Spatlese'), 'Rovada' ('Jonkheer van Tets' × 'Rosetta') [9].

In the Research Institute of Fruit and ornamental Plants (Bojnice, Slovakia), the selection program for red currant was conducted since 1959, 140 combinations of crossing were carried out, the 'Rote Spatlese' variety proved to be a valuable parent form. In 1977, the state assortment of Czechoslovakia included the white-fruit varieties 'Blanka', 'Primus' ('Rote Spatlese' $\times$ 'Ped Lake') [9], which are still the main cultivated varieties in many countries of the world. From the combination of 'Jonkheer van Tets' $\times$ 'Rote Spatlese' (1985-1992) 'Detvan', 'Hron' were selected, known as highly productive, very long-raceme varieties, up to 25-30 berries per shrub.

The 'Rote Spatlese' variety was used in the selection program as the initial form for red currant at the Institute of Horticulture (Lviv branch) of the National Academy of Agricultural Sciences of Ukraine, where the varieties Charodeyka ('Jonkheer van Tets' $\times$ 'Rote Spatlese') and Yaroslavna ('Rote Spatlese' $\times$ 'Jonkheer van Tets') were created on the basis of this genotype, which until 2020 were in the State Register of Plant varieties suitable for Dissolution in Ukraine [10].

The Russian Research Institute of Fruit Crop Breeding (Russia) has been breeding red currant since 1984, and according to the results of variety studies, the 'Rote Spatlese' variety was included in hybridization as a complex source of valuable traits for the crop $[11,12]$.

The purpose of the research was to create highly productive, bio- and abiotic-resistant red currant varieties with high commercial and taste qualities of berries for fresh consumption and processing. 


\section{Materials and methods}

Hybridization was carried out at the experimental sites of the Russian Research Institute of Fruit Crop Breeding (VNIISPK). The Research Institute is located in the European part of Russia, $368 \mathrm{~km}$ to the southwest of Moscow $\left(53^{\circ} 00^{\prime} \mathrm{N}, 36^{\circ} 00^{\prime} \mathrm{E}\right)$, in the Orel suburb.

As one of the parent forms, the 'Rote Spatlese' variety was used, as the other one varieties of different geographical and genetic origin were taken. Considering the selffertility of the crop, hybridization was carried out with the castration of flowers in the state of a large bud. The castrated flowers were pollinated with pre-prepared pollen of the paternal form and covered with insulators made of non-woven material that protect against pollination by insects. The cultivation of hybrid seedlings, their study on experimental plots, and the selection of notable forms were carried out in accordance with the methodological recommendations "Program and methodology of variety study of fruit, berry and nut crops" [13]. On the site of variety study, selected forms were planted at $0.5 \mathrm{~m}$ in a row, the row spacing was $3.5 \mathrm{~m}$. The plants were grown without artificial irrigation. Protective measures were not carried out to identify the degree of susceptibility of breeding forms to the main pests and diseases at the experimental site. The degree of damage to red currant varieties by powdery mildew (Sphaerotheca mors-uvae Berk. et Curt.) and damage by Dysaphis crataegi (Capitophorus ribis L.) were evaluated by a 5-point scale, where $0-$ no damage (affect), 5 - very strong: more than $1 / 2$ of the shoot length was affected (damaged), more than $70 \%$ of the leaves. The assessment of resistance was carried out according to the maximum score of disease development and pest population.

Statistical processing of the research results was carried out by variance analysis method (ANOVA). The significant difference between the varieties (LSD) was calculated with a 5\% significance level. The calculations were performed using the Microsoft Excel 2016 software package.

\section{Results and discussion}

In 1974, the VNIISPK (formerly the Orel Fruit and Berry Experimental Station) for the first time created a collection of red currant varieties, including 22 varieties (currently, the general collection includes more than 80 varieties of domestic and foreign selection). One of the varieties accepted for the experiment was 'Rote Spatlese'. As a result of variety studies, it was recommended for selection as a source of long-raceme, resistance to powdery mildew, late ripening of berries, and high self-fertility. Since the beginning of selection work (1984) and for 10 years, the 'Rote Spatlese' variety has been involved in crosses as a female or male parent form. Varieties of various origins and some species forms were taken as the second parent (Table 1).

Table 1. Red currant varieties used in crosses with 'Rote Spatlese'

\begin{tabular}{|l|l|}
\hline \multicolumn{1}{|c|}{ Female parent form,,} & \multicolumn{1}{|c|}{ Male parent form, ô } \\
\hline 'Jonkheer van Tets', 'Maarse's Prominent', & 'Jonkheer van Tets', 'Maarse's Prominent,' \\
'Minnesota', 'Red Lake', 'Red Dutch', & 'Red Lake', 'Red Dutch', 'Cascade', \\
'Perfection', 'Cascade', 'Rondom', & 'Rondom', 'Viksne', 'Rosa Hollandische', \\
'Viksne', 'Rosa Hollandische', 'Gonduin', & 'Gonduin', 'Nataly', 'Rachnovskaja', \\
'Erstling aus Vierländen', 'Nataly', & 'Chulkovskaja', 'Smoljaninovska', 'Englische \\
'Nenagljadnaja', 'Rachnovskaja', & grosse weisse', 'White Dutch', 'White Grape', \\
'Stjedraja', 'Varshevicha', 'Chulkovskaja', & sample 310-34 R. atropurpureum C.A. Mey., \\
'Smoljaninovska', 'Englische grosse & sample 258-112 \\
weisse', 'White Dutch', 'White Grape' & R. Meyeri Maxim. \\
\hline
\end{tabular}


When using 'Rote Spatlese' as the male parent form, no ovary was obtained in any of the 18 crossing combinations. The combinations in which the cultivar 'Rote Spatlese' was pollinated with the varieties shown in Table 2 were effective.

Table 2. Crossing combinations effectiveness

\begin{tabular}{|c|c|c|c|c|c|c|}
\hline \multirow{2}{*}{$\begin{array}{l}\text { Female } \\
\text { parent } \\
\text { form, },+\end{array}$} & \multirow{2}{*}{$\begin{array}{ll}\text { Male } & \text { parent } \\
\text { form, } \delta & \end{array}$} & \multirow{2}{*}{$\begin{array}{l}\text { Berry } \\
\text { set, } \\
\%\end{array}$} & \multirow{2}{*}{$\begin{array}{l}\text { Seedlings } \\
\text { obtained, } \\
\text { pcs. }\end{array}$} & \multicolumn{3}{|l|}{ Allocated, pcs. } \\
\hline & & & & $\begin{array}{l}\text { selected } \\
\text { seedlings ( } \% \\
\text { of seedlings in } \\
\text { the family) }\end{array}$ & $\begin{array}{l}\text { elite } \\
\text { seedlings }\end{array}$ & varieties \\
\hline \multirow[t]{9}{*}{$\begin{array}{l}\text { 'Rote } \\
\text { Spatlese' }\end{array}$} & $\begin{array}{l}\text { 'Jonkheer van } \\
\text { Tets' }\end{array}$ & 29.0 & 242 & $56(23.1)$ & 9 & 7 \\
\hline & 'Red Lake' & 29.2 & 144 & $28(19.4)$ & 2 & 2 \\
\hline & 'Minnesota' & 26.8 & 40 & $12(30.0)$ & 2 & 2 \\
\hline & $\begin{array}{l}\text { 'Maarse's } \\
\text { Prominent' }\end{array}$ & 13.0 & 39 & $11(28.2)$ & 2 & 2 \\
\hline & 'Chulkovskaja' & 49.8 & 75 & $22(29.3)$ & 1 & 0 \\
\hline & 'White Dutch' & 27.5 & 62 & $6(9.7)$ & 1 & 0 \\
\hline & $\begin{array}{l}\text { 'Rosa } \\
\text { Hollandische' }\end{array}$ & 13.4 & 63 & $13(20.6)$ & 0 & 0 \\
\hline & 'Cascade' & - & 39 & $9(23.1)$ & 0 & 0 \\
\hline & 'Red Dutch' & 27.0 & 33 & $1(3.0)$ & 0 & 0 \\
\hline $\mathrm{V}, \%$ & & 42.9 & & & & \\
\hline
\end{tabular}

A high set of berries after castration of flowers was observed in the combination of 'Rote Spatlese' 'Chulkovskaja' - 49.8\%. In 5 out of 10 combinations of artificial pollination of berries, from 29.2 to $26.8 \%$ were set. When pollinating 'Rote Spatlese' with pollen of the 'Maarse's Prominent' and 'Rosa Hollandische' varieties, berries were obtained in the range of $13 \%$. The number of hybrid seedlings varied from 242 pieces in the 'Rote Spatlese' $\times$ 'Jonkheer van Tets' family to 33 pieces in the 'Rote Spatlese' $\times$ 'Red Dutch' combination. The yield of selected seedlings in 8 breeding families was in the range of 20 $30 \%$. New varieties of red currant were isolated from 4 cross-breeding combinations: from pollination of the 'Rote Spatlese' variety by the 'Jonkheer van Tets' and 'Red Lake' varieties, which showed a positive result in the selection programs of other research institutions, as well as by the 'Minnesota' and 'Maarse's Prominent' varieties. The greatest selection value was shown by the 'Rote Spatlese' $\times$ 'Jonkheer van Tets' family, from which 7 late-maturing varieties of red currant were obtained. A brief economic and biological characteristic of the red currant varieties selected by VNIISPK, obtained on the basis of the 'Rote Spatlese' genotype, are presented in Table 3.

Table 3. Economic and biological characteristics of red currant varieties (2018-2020)

\begin{tabular}{|c|c|c|c|c|c|c|c|}
\hline \multirow[t]{2}{*}{ Variety* } & \multicolumn{2}{|c|}{$\begin{array}{l}\text { Morphological features } \\
\text { of a bush }\end{array}$} & \multirow[t]{2}{*}{ Yield, t/ha } & \multirow{2}{*}{$\begin{array}{l}\text { Raceme } \\
\text { length, } \\
\mathrm{cm}^{* *}\end{array}$} & \multirow[t]{2}{*}{ Ratio } & \multicolumn{2}{|c|}{ Maximum score of damage } \\
\hline & $\begin{array}{l}\text { growth } \\
\text { power }\end{array}$ & $\begin{array}{l}\text { compactibil } \\
\text { ity }\end{array}$ & & & & $\begin{array}{l}\text { Sphaerotheca } \\
\text { mors-uvae } \\
\text { Berk. et Curt. }\end{array}$ & $\begin{array}{l}\text { Capitophorus } \\
\text { ribis L. }\end{array}$ \\
\hline \multicolumn{8}{|c|}{ 'Rote Spatlese'×'Jonkheer van Tets' selection family } \\
\hline Asora* & $\begin{array}{l}\text { medium- } \\
\text { grown }\end{array}$ & $\begin{array}{l}\text { semi- } \\
\text { branchy }\end{array}$ & $12.2 \pm 2.7$ & $8.0 \pm 0.6$ & 2.5 & 1.0 & 1.0 \\
\hline $\begin{array}{l}\text { Valentinov } \\
\mathrm{ka}^{*}\end{array}$ & $\begin{array}{l}\text { heavy- } \\
\text { grown }\end{array}$ & $\begin{array}{l}\text { poor- } \\
\text { branchy }\end{array}$ & $15.1 \pm 1.0$ & $10.0 \pm 0.9$ & 2.7 & 2.0 & 3.0 \\
\hline Dana* & heavy- & semi- & $18.8 \pm 1.9$ & $10.5 \pm 1.4$ & 3.4 & 3.0 & 3.0 \\
\hline
\end{tabular}




\begin{tabular}{|c|c|c|c|c|c|c|c|}
\hline & grown & branchy & & & & & \\
\hline Dar Orla* & $\begin{array}{l}\text { heavy- } \\
\text { grown }\end{array}$ & $\begin{array}{l}\text { semi- } \\
\text { branchy. }\end{array}$ & $19.7 \pm 2.5$ & $10.0 \pm 1.2$ & 2.7 & 2.0 & 2.0 \\
\hline Ogonyok & $\begin{array}{l}\text { heavy- } \\
\text { grown }\end{array}$ & $\begin{array}{l}\text { semi- } \\
\text { branchy }\end{array}$ & $14.2 \pm 3.1$ & $12.0 \pm 0.4$ & 3.0 & 3.0 & 3.0 \\
\hline $\begin{array}{l}\text { Orlovchank } \\
a^{*}\end{array}$ & $\begin{array}{l}\text { medium- } \\
\text { grown }\end{array}$ & branchy & $16.9 \pm 0.8$ & $9.7 \pm 1.4$ & 3.0 & 3.0 & 3.0 \\
\hline $\begin{array}{l}\text { Podarok } \\
\text { Leta* }\end{array}$ & $\begin{array}{l}\text { medium- } \\
\text { grown }\end{array}$ & $\begin{array}{l}\text { semi- } \\
\text { branchy }\end{array}$ & $19.5 \pm 1.6$ & $10.7 \pm 1.2$ & 2.3 & 1.0 & 1.0 \\
\hline \multicolumn{8}{|c|}{ 'Rote Spatlese'×'Red Lake' selection family } \\
\hline $\begin{array}{l}\text { Bayana* } \\
\text { (white- } \\
\text { fruit) }\end{array}$ & $\begin{array}{l}\text { medium- } \\
\text { grown }\end{array}$ & $\begin{array}{l}\text { poor- } \\
\text { branchy }\end{array}$ & $14,8 \pm 1,6$ & $10,0 \pm 1,7$ & 4,3 & 3,0 & 4,0 \\
\hline $\begin{array}{l}\text { Selyanochk } \\
\text { a }\end{array}$ & $\begin{array}{l}\text { medium- } \\
\text { grown }\end{array}$ & $\begin{array}{l}\text { semi- } \\
\text { branchy }\end{array}$ & $12,8 \pm 0,6$ & $10,0 \pm 1,2$ & 4,1 & 4,0 & 1,0 \\
\hline \multicolumn{8}{|c|}{ 'Rote Spatlese' ×'Minnesota' selection family } \\
\hline $\begin{array}{l}\text { Osipovskay } \\
\text { a* }\end{array}$ & $\begin{array}{l}\text { heavy- } \\
\text { grown }\end{array}$ & branchy & $15,3 \pm 3,1$ & $11,0 \pm 1,2$ & 3,4 & 3,0 & 3,0 \\
\hline $\begin{array}{l}\text { Orlovskaya } \\
\text { Zvezda }\end{array}$ & $\begin{array}{l}\text { heavy- } \\
\text { grown }\end{array}$ & $\begin{array}{l}\text { poor- } \\
\text { branchy }\end{array}$ & $10,5 \pm 1,6$ & $12,1 \pm 1,0$ & 2,7 & 2,0 & 3,0 \\
\hline \multicolumn{8}{|c|}{ 'Rote Spatlese'×'Maarse's Prominent' selection family } \\
\hline $\begin{array}{l}\text { Marmeladn } \\
\text { itsa* }\end{array}$ & $\begin{array}{l}\text { medium- } \\
\text { grown }\end{array}$ & $\begin{array}{l}\text { semi- } \\
\text { branchy }\end{array}$ & $10,8 \pm 0,8$ & $8,0 \pm 0,3$ & 3,2 & 3,0 & 1,0 \\
\hline Ustina & $\begin{array}{l}\text { heavy- } \\
\text { grown }\end{array}$ & $\begin{array}{l}\text { semi- } \\
\text { branchy }\end{array}$ & $11,8 \pm 1,7$ & $11,0 \pm 1,5$ & 3,3 & 4,0 & 1,0 \\
\hline $\mathrm{LSD}_{05}$ & & & 2,9 & 1,0 & & & \\
\hline
\end{tabular}

Note: * - red currant varieties selected by VNIISPK, included in the State Register of Breeding Achievements approved for use in the Russian Federation;

** - raceme length with leafstalk.

Varieties Valentinovka, Bayana, Orlovskaya Zvezda are characterized by a poorbranchy habitus of the shrub. The following cultivars are distinguished by high yield (15.1 19.7 t/ha): Valentinovka, Dana, Dar Orla, Orlovchanka, Podarok Leta, Osipovskaya. Varieties Marmeladnitsa, Asora, Orlovchanka have a raceme of medium length, the other varieties have a long raceme, with a long leafstalk, convenient for hand-harvesting. In central Russia, red currant berries accumulate a small amount of sugars (6.58-9.30\%) and have a high content of organic acids (up to 3.0\% and higher) [14]. The 'Red Dutch' variety used as a control, according to long-term data of the VNIISPK biochemical laboratory, on average contains $7.35 \%$ sugars and $2.59 \%$ organic acids and its Ratio is 2.8 points. The Osipovskaya and Selyanochka varieties have a higher Ratio and higher berry taste qualities. The white-fruit variety of Bayana stands out among other varieties with the dessert berry taste. High complex resistance to Sphaerotheca morsuvae Berk. et Curt. and Capitophorus ribis L. eis showed by Asora, Dar Orla, Podarok Leta verieties. The average berry weight varies from $0.48 \mathrm{~g}$ in the Ustina variety to $0.73 \mathrm{~g}$ in the Asora variety (Figure 1). 


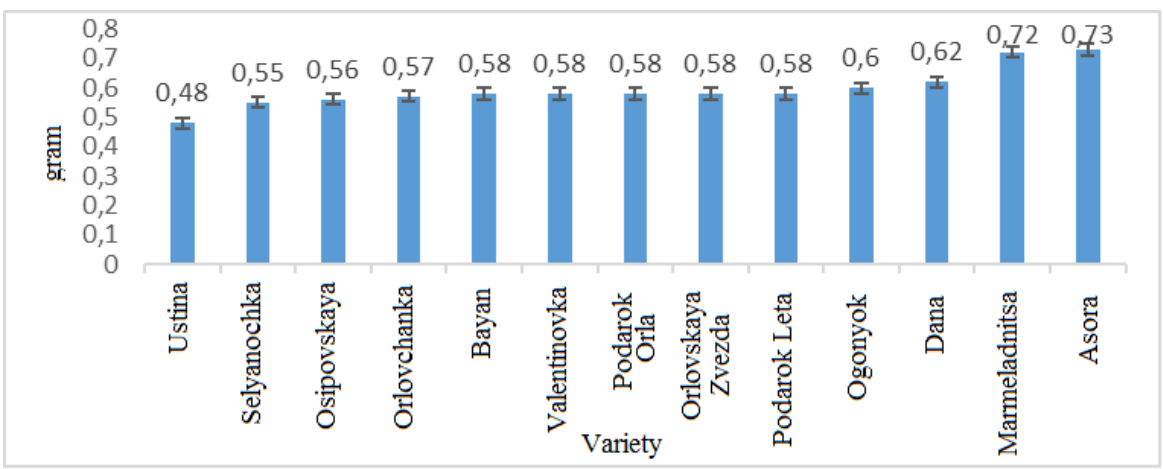

Fig. 1. Average weight of red currant berry varieties

\section{Conclusion}

The involvement of the 'Rote Spatlese' variety in selection allowed to obtain 13 latematuring, high-yielding varieties of red currant, the main part of which has a long raceme. The greatest breeding value was shown by the family 'Rote Spatlese' $\times$ 'Jonkheer van Tets', from which 7 varieties of red currant were obtained: Asora, Valentinovka, Dana, Dar Orla, Ogonyok, Orlovchanka, Podarok Leta. The combinations in which 2 varieties were selected were also effective: 'Rote Spatlese' $\times$ 'Red Lake' - Bayana (white-fruited), Selyanochka; 'Rote Spatlese' $\times$ 'Minnesota' - Osipovskaya, Orlovskaya Zvezda; 'Rote Spatlese' $\times$ 'Maarse's Prominent' - Marmeladnitsa, Ustina. The research results show that the cultivar 'Rote Spatlese ' is the most valuable initial form in red currant selection for late ripening, longraceme, high productivity.

\section{References}

1. Electronic source (2020) http://www. botanical-online.com

2. M. A. Makarkina, T. V. Yanchuk, Vestnik of the Russian Agricultural Science, 4, 10 (2018)

3. O.V. Panfilova, O.D. Golyaeva, Agricultural Biology, 52(5), 1056 (2017)

4. O. Panfilova, M. Tsoy, O. Kalinina, S. Knyazev, E3S Web of Conferences, 176, 03014 (2020)

5. Panfilova, O.V., Knyazev, S.D., Golyaeva, O.D., Kalinina, O.V. Bulgarian, Journal of Agricultural Science, 1

6. G. Fenu, E. Mattana, G. Bacchetta, Oryx, 46(2), 219 (2012)

7. Electronic source (2020) http://florapedia.ru

8. K. Kampuss, S. Strautina, S. Kampuse, XXVII International Horticultural Congress, 760,53 (2007)

9. K. Kampuss, H. L. Pedersen, Small Fruits Review, 2(3), 47 (2003)

10. J. Cvopa, E. Cvopava, Uroda, 25(10), 2 (1977)

11. State Register of Plant Varieties Suitable for Dissemination in Ukraine in 2019, Ministry of Agrarian Policy and Food, Kyiv (2019)

12. O. Golyaeva, O. Kurashev, S. Knyazev, A. Bahotskaya, Vestnik of the Russian Agricultural Science, 4, 41 (2020) 
13. Program and methods of variety investigation of fruit, berry and nut crops, 608 (1999)

14. M. A. Makarkina, O.D.Golyaeva, Horticulture and Viticulture, 2, 28 (2020) 